4

Research Article:

\title{
Sex differences and estradiol effects in MAPK and Akt cell signalling across subregions of the hippocampus
}

\author{
Paul A. S. Sheppard ${ }^{1,2, a}$, Tanvi A. Puri ${ }^{2,3}$, \& Liisa A. M. Galea ${ }^{1,2,3,{ }^{*}}$
}

1) Department of Psychology, University of British Columbia, Vancouver, BC, Canada

2) Djavad Mowafaghian Centre for Brain Health, University of British Columbia, Vancouver, BC, Canada

3) Graduate Program in Neuroscience, University of British Columbia, Vancouver, BC

Email addresses: PASS - psheppa5@uwo.ca, TAP - tanvi.puri@psych.ubc.ca, LAMG - liisa.galea@ubc.ca

Short title: Sex and estradiol differences in hippocampal cell signalling

* Address correspondence to:

Dr. Liisa Galea

Djavad Mowafaghian Centre for Brain Health

University of British Columbia

2215 Wesbrook Mall

Vancouver, BC

Canada, V6T $1 \mathrm{Z3}$

Tel: +1 (604) 8226536

Email: liisa.galea@ubc.ca

Number of Tables: 2

Number of Figures: 5

Number of Supplementary Figures: 2

Word count: Abstract - 240, Body - 4899

Keywords: ovariectomy, dentate gyrus, CA1, Akt, ERK, GSK-3ß, p38, JNK, p70S6K

a Present address: Schulich School of Medicine and Dentistry, Robarts Research Institute, University of Western Ontario, London, ON, Canada 


\section{Abstract}

Introduction: Rapid effects of estrogens within the hippocampus of rodents are dependent upon cell signaling cascades, and activation of these cascades by estrogens varies by sex. Whether these pathways are rapidly activated within the dentate gyrus (DG) and CA1 by estrogens and across the anatomical longitudinal axis has been overlooked.

44 Methods: Gonadally-intact female and male rats were given either vehicle or physiological systemic low

45

46

47

48

49

50

51

52

53

54

55

56

57

58

59 $(1.1 \mu \mathrm{g} / \mathrm{kg})$ or high $(37.3 \mu \mathrm{g} / \mathrm{kg})$ doses of $17 \beta$-estradiol thirty minutes prior to tissue collection. To control for the effects of circulating estrogens, an additional group of female rats was ovariectomized (OVX) and administered $17 \beta$-estradiol. Brains were extracted and tissue punches of the CA1 and DG were taken along the longitudinal hippocampal axis (dorsal and ventral) and analyzed for key MAPK and Akt cascade phosphoproteins.

Results: Intact females had higher Akt pathway phosphoproteins (pAkt, pGSK-3 $\beta$, pp70S6K) than males in the DG (dorsal, ventral) and lower pERK1/2 in the dorsal DG. Most effects of 17 $\beta$-estradiol on cell signalling occurred in OVX animals. In OVX animals, $17 \beta$-estradiol increased cell signalling of MAPK and Akt phosphoproteins (pERK1/2, pJNK, pAkt, pGSK-3 $\beta$ ) in the CA1 and pERK1/2 and pJNK DG.

Discussion/Conclusions: Systemic $17 \beta$-estradiol treatment rapidly alters phosphoprotein levels in the hippocampus dependent on reproductive status and intact females have greater expression of Akt phosphoproteins than intact males across the hippocampus. These findings shed light on underlying mechanisms of sex differences in hippocampal function and response to interventions that affect MAPK or Akt signaling. 


\section{Introduction}

Estrogens rapidly affect object and spatial memory consolidation (1-3), short-term social memory $(2,4)$, response learning (5), neurogenesis (6), and spine and synapse formation (7-9). Most of these effects of estrogens occur rapidly and likely via cell signaling pathways after binding with the estrogen receptors (ERs). Estrogens exert both rapid (non-classical) and delayed (classical) actions. The classical actions of estrogens occur when they bind with ERs that dimerize, translocate to the nucleus, and act directly to affect gene expression (10). In contrast, the rapid effects of estrogens initiate a myriad of intracellular processes, including the activation of cell signaling cascades (reviewed in (2-4)). Rapid (within minutes) or delayed (within hours) effects of estrogens on molecular, cellular, and behavior can vary by brain region (reviewed in $(2,3,11)$ ). Rapid effects of estrogens on social, object, and spatial location recognition rely on signaling through mitogen-activated protein kinase (MAPK) and Akt (protein kinase B) pathways, whereas the delayed effects are driven predominantly by ER-estrogen response element interactions and effects on gene expression $(2,3)$. There is, however, overlap in these effects, with the less well understood rapid effects occurring concurrently with the more established delayed effects. Thus, understanding the mechanisms, such as cell signaling cascades, through which the rapid effects act is imperative to a comprehensive view of actions by estrogens.

Two of the most studied cell signaling cascades are the MAPK and Akt pathways. These pathways are involved in a number of processes including cell proliferation, migration, and survival, apoptosis, metabolism, differentiation, immune responses, and development (12-15). There is much crosstalk between MAPK and Akt pathways $(16,17)$, and these pathways often act in parallel to elicit similar downstream mechanisms and outputs in complementary or synergistic manners $(16,18,19)$. However, little work has investigated both pathways in the same animals and those that do typically only measure specific phosphoproteins of interest, despite the intricacy and interconnectedness of these signaling cascades.

Sex differences have been noted in the influence of $17 \beta$-estradiol on the hippocampus. In older rats, acute $17 \beta$-estradiol increases spine density in older females but decreases spine density in males (20). Furthermore, whereas gonadectomy reduces spine density in both males and females in the CA1 (21-23), estradiol increases spine density in females $(24,25)$ but not in males $(22)$. Few studies have investigated sex differences in the effects of $17 \beta$-estradiol on cell signalling. Female rats have higher baseline levels of phosphorylated extracellular signal-regulate protein kinase 1/2 (pERK1/2; both p44

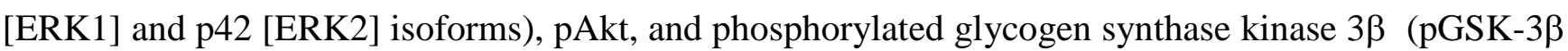
in the prefrontal cortex (prelimbic and infralimbic cortices), nucleus accumbens, and rostral caudate putamen of rats than male rats (26). However, to our knowledge, no studies have examined sex differences in expression of both MAPK and Akt phosphoproteins in different subregions of the hippocampus thus far. Few studies have explored sex differences in these cell signalling proteins after exposure to $17 \beta$-estradiol. Intrahippocampal $17 \beta$-estradiol increases dorsal hippocampal pAkt and pERK2 in OVX females, but not in gonadally-intact or castrated males (27). Similarly, 17 $\beta$-estradiol increases pERK1/2 in anteroventral periventricular (AVPV) nucleus and the medial preoptic area in females but not in males (28). Thus, there is a dearth of evidence exploring influence of $17 \beta$-estradiol on cell signalling across the sexes and within subregions across the hippocampus. 
The hippocampus is a heterogeneous structure with distinct subfields across the longitudinal axis (dorsal, ventral), as well as dentate gyrus (DG), CA3 and CA1 subregions. Based on gene expression, receptor levels, activity, and connectivity, the dorsal hippocampus is thought to be important for learning and memory, whereas the ventral region is more important for regulation of stress and anxiety (29). Estradiol rapidly increases cell proliferation in both the dorsal and ventral DG $(6,30)$. Furthermore, $17 \beta$ estradiol increases apical dendritic spines in the CA1 region but not in the DG $(21,31)$. Given that $17 \beta$ estradiol influences both dorsal and ventral hippocampal plasticity, it is important to examine possible subregional (i.e. DG and CA1) effects across the longitudinal axis that show rapid $17 \beta$-estradiol action in both sexes.

Most previous studies have examined the effects of estrogens on cell signaling in either the whole hippocampus (32), dorsal hippocampus (27,33-35), or dorsal CA1 (36) in OVX female rodents. Estrogens rapidly increase phosphorylated (activated) proteins in the MAPK and Akt cascades including the MAPKs pERK and pJNK and Akt pathway proteins pAkt, pGSK-3 $\beta$, and p70S6K. Another MAPK protein, p38, has divergent effects from other MAPKs and is minimally affected in the hippocampus by the delayed effects of $17 \beta$-estradiol treatment in OVX female rats (37). However, even in studies investigating the rapid effects of $17 \beta$-estradiol on cell signaling cascades, methodologies (including, for example, timing and/or dose of $17 \beta$-estradiol treatment) vary and make comparison between pathways and proteins difficult.

The current study was designed to examine sex differences in cell signaling cascades, with and without $17 \beta$-estradiol, in the dorsal and ventral fields of DG and CA1 of the hippocampus. We hypothesized that sex and $17 \beta$-estradiol would differentially affect MAPK and Akt cell signaling cascades and that these differences would vary by region across the longitudinal axis. Furthermore, we hypothesized that in OVX rats $17 \beta$-estradiol would increase activation of cell signaling cascades in both the CA1 and DG, but that these effects may be more prominent in the dorsal versus ventral axis.

\section{Methods}

Animals

Ten- to eleven-week-old, gonadally intact female $(n=65)$ and male $(n=19)$ Sprague-Dawley rats (Charles River, St. Constant, Quebec, Canada) were received at the University of British Columbia and pair-housed (with the exception of one triple-housed cage of males) upon arrival. Rats were housed in transparent polyurethane bins $(48 \times 27 \times 20 \mathrm{~cm})$ with aspen chip bedding and were given Purina rat chow and tap water ad libitum. Rats were maintained under a 12/12h light/dark cycle (lights on 07:00h) in standard housing conditions ( $21 \pm 1^{\circ} \mathrm{C} ; 50 \pm 10 \%$ humidity). Animals were handled for 5 minutes each, every other day prior to the experiment for a minimum of five handling sessions. Animals were 12-13 weeks old when administered $17 \beta$-estradiol and brains were collected. The means and standard errors of the means for body mass were as follows: females $295 \pm 3.55 \mathrm{~g}$ and males $477 \pm 7.51 \mathrm{~g}$. To determine estrous phase during testing, intact females underwent vaginal lavage immediately following tissue collection. Lavage samples were stained with cresyl violet and estrous phase was evaluated (38). One week following arrival, 36 female rats were bilaterally ovariectomized using aseptic techniques under isoflurane anesthesia, with ketamine (30 mg/kg, Bimeda-MTC, Cambridge, ON), xylazine (2 mg/kg, Bayer HealthCare, Toronto, ON), and bupivacaine (applied locally; $4 \mathrm{mg} / \mathrm{kg}$, Hospira Healthcare 
142

Corporation, Montreal, QC). Following surgery, rats were single-housed and allowed to recover for at least one week before testing. All experiments were conducted in accordance with the ethical guidelines set by the Canada Council for Animal Care and were approved by the University of British Columbia Animal Care Committee. All efforts were made to reduce the number and the suffering of animals.

\section{Treatment}

Rats were subcutaneously administered $1.1 \mu \mathrm{g} / \mathrm{kg} 17 \beta$-estradiol in sesame oil (low $17 \beta$-estradiol; Females $\mathrm{n}=10$, Males $\mathrm{n}=6$, OVX n=13), $37.3 \mu \mathrm{g} / \mathrm{kg} 17 \beta$-estradiol in sesame oil (high $17 \beta$-estradiol; Females $n=10$, Males $n=7$, OVX $n=13$ ), or sesame oil vehicle (Females $n=9$, Males $n=6$, OVX $n=10$ ) 30 minutes prior to tissue extraction. These sample sizes were selected as they have previously produced large effect sizes (Cohen's $d>0.8$ ) in similar analyses (6,39). Estradiol doses were chosen because they result in circulating levels of $17 \beta$-estradiol observed on the morning of proestrus (high 17 $\beta$-estradiol) or during diestrus (low 17 $\beta$-estradiol)(40), and both doses enhance cell proliferation 30 minutes after injection in OVX females $(6,30)$. There were no significant differences in average body mass per treatment group (all ps>0.12). All rats were injected between 09:00h and 11:15h. Rats were sacrificed by decapitation, and brains were excised, hemisected, and flash-frozen on dry ice.

\section{Brain tissue processing}

Brains were sliced into $300 \mu \mathrm{m}$ sections at $-10^{\circ} \mathrm{C}$ using a Leica CM3050 S cryostat (Nußloch, Germany). Punches were taken from the DG and CA1 of both the dorsal and ventral horns of the hippocampus using modified 18G needles with an internal punch diameter of $0.838 \mathrm{~mm}$ (see Figure 1). Tissue was collected and homogenized using an Omni Bead Ruptor (Omni international, Kennesaw, GA) with $40 \mu \mathrm{l}$ of cold lysis buffer. Homogenates were centrifuged at $4^{\circ} \mathrm{C}$ and $1000 \times \mathrm{g}$ for $15 \mathrm{~min}$ then stored at $-20^{\circ} \mathrm{C}$. Total protein concentrations in homogenates were quantified using the Pierce Micro BCA Protein Assay Kit (ThermoFisher Scientific) and used according to manufacturer instructions, with samples run in triplicates.

\section{Phosphoprotein quantification}

Multiplex electrochemiluminescence immunoassay kits (MAPK Kinase Phosphoprotein and Akt Signaling Panel Assay Whole Cell Lysate Kits) were purchased from Meso Scale Discovery (Rockville, $\mathrm{MD}$ ) and used according to manufacturer instructions - with the exception of incubating the samples at $4^{\circ} \mathrm{C}$ overnight - to measure phosphoprotein levels. Electrochemiluminescent assays are highly selective and quantitative, produce low background, have a broad dynamic range of detection, and require relatively small volume of sample compared to ELISAs and Western blots $(41,42)$. The antibody precoated plates allowed for the simultaneous quantification of the following phosphoproteins: pERK1/2 (combined p42 and p44 isoforms), pJNK, and pp38 (MAPK kit) and pAkt, pGSK-3 $\beta$, and pp70S6K (Akt kit). Samples were run in technical replicates and plates were read with a Sector Imager 2400 (Meso Scale Discovery) using the Discovery Workbench 4.0 (Meso Scale Discovery). Phosphoprotein values were averaged across technical replicates and normalized to total protein concentrations for statistical analyses (as in (39,43-45)). Inter- and intra-assay coefficients of variation (CV) were below $10 \%$. Phosphoprotein signal data were excluded when the CV between duplicates exceeded this threshold. 


\section{Statistical analyses}

Statistical analyses were run using Statistica v.8.0 (StatSoft Inc, Tulsa, OK) software. Bartlett’s homogeneity of variance tests were performed and, in analyses where homogeneity of variance was violated, data were subjected to a Box-Cox transformation (lambda=-0.5). Two-way ANOVAs were conducted for each analyte and region with treatment (oil, low $17 \beta$-estradiol, high $17 \beta$-estradiol) and sex (female, male) as between groups factors. To determine if there were baseline differences between males and females, vehicle treated rats were used as reference for calculation of percent differences. Phosphoprotein levels in intact vehicle treated female rats were compared across the estrous cycle (proestrus vs non-proestrus, corresponding to high and low $17 \beta$-estradiol phases, respectively) using Welch's t-tests. One-way ANOVAs were conducted for each analyte and region in the OVX animals, with treatment (vehicle, low $17 \beta$-estradiol, high $17 \beta$-estradiol) as the between-subjects factor. Post hoc comparisons used Newman-Keuls. When one-way ANOVAs violated homogeneity of variance, BrownForsythe ANOVAs were performed with Dunnett's T3 post hocs. A priori analyses were subjected to Bonferroni correction. Any statistical outliers ( \pm 2 standard deviations from the group mean) were removed. Statistical significance was set at $\mathrm{p}<0.05$. Eta squared $\left(\eta^{2}\right)$ and Cohen's $d$ effect sizes were calculated where appropriate.

\section{$\underline{\text { Results }}$}

First, we analysed the effects of estrous cycle on phosphoproteins across the dorsal/ventral axis and in all regions. There were no significant effects (all ps>0.245; Supplementary Figures 1 and 2) and, as such, these were not considered further.

\section{Intact males and females}

Akt pathway: Females have higher levels of Akt pathway phosphoproteins in the dorsal and ventral dentate gyrus but not in the CA1 region.

Female rats had up to $400 \%$ higher levels of pAkt, pGSK-3 $\beta$, and pp70S6K than males in the dorsal and ventral DG, but not in the CA1 region. Females had greater phosphoprotein signal than males for each analyte in the Akt pathway in both the dorsal (109-400\%) and ventral DG (123-262\%; main effects of sex: dorsal DG: $p A k t-F_{(1,39)}=58.51, p<0.0001, \eta^{2}=0.262$; $p G S K-3 \beta-F_{(1,36)}=37.21, p<0.0001$, $\eta^{2}=0.488$; pp70S6K $-\mathrm{F}_{(1,39)}=22.33, \mathrm{p}<0.0001, \eta^{2}=0.358$; Figure $2 \mathrm{~A}$; ventral DG: $\mathrm{pAkt}-\mathrm{F}_{(1,36)}=51.22$, $\mathrm{p}<0.0001, \eta^{2}=0.581$; pGSK-3 $\beta-\mathrm{F}_{(1,35)}=15.67, \mathrm{p}=0.0004, \eta^{2}=0.292 ; \mathrm{pp} 70 \mathrm{~S} 6 \mathrm{~K}-\mathrm{F}_{(1,37)}=11.96, \mathrm{p}=0.0014$, $\eta^{2}=0.205$; Figure 2B). There were no other main or interaction effects in this pathway (all ps $>0.094$ ).

High $17 \beta$-estradiol increased dorsal CA1 pAkt by $36 \%$ over vehicle treatment in females ( $\mathrm{p}=0.05$, Cohen's $d=0.929$ ), but there were no other significant pairwise comparisons (interaction: $F_{(2,37)}=3.731$, $p=0.0334, \eta^{2}=0.143$; Figure 2C)). Although there were main effects of sex in the dorsal CA1 in the Akt pathway (pAkt $-\mathrm{F}_{(1,37)}=7.725, \mathrm{p}=0.0085, \eta^{2}=0.148$; pGSK-3 $\beta-\mathrm{F}_{(1,38)}=7.608, \mathrm{p}=0.0089, \eta^{2}=0.143$; pp70S6K $-F_{(1,39)}=5.796, p=0.0209, \eta^{2}=0.117$; Figure 2C), a priori comparisons failed to show a sex differences in the vehicle conditions (all ps $>0.05$; Figure $2 \mathrm{C}$ ). There were no other significant effects in the ventral CA1 (all ps>0.079; Figure 2D). 
MAPK pathway: Males had greater pERK1/2 in the dorsal dentate gyrus than females. $17 \beta$-estradiol reduced pp38 in the ventral DG in intact females but not in intact males.

Male rats had significantly greater pERK1/2 (292\%) than females in dorsal DG ( $\mathrm{p}=0.0004$, Cohen's $d=1.389$; main effect of sex: $F_{(1,37)}=23.87, p<0.0001, \eta^{2}=0.372$; Figure 3A). Despite the significant main effects for sex for the other analytes ( $\mathrm{pJNK}-\mathrm{F}_{(1,41)}=5.832, \mathrm{p}=0.0203, \eta^{2}=0.117$; pp38 $\left.F_{(1,42)}=38.25, p<0.0001, \eta^{2}=0.427\right)$, there were no significant differences in pJNK or pp38 between vehicle treated males and females (ps>0.05) or other significant main or interaction effects in the dorsal DG (all ps>0.257).

Both doses of $17 \beta$-estradiol decreased pp38 in the ventral DG of females (low 17 $\beta$-estradiol: $\mathrm{p}<0.0001$, Cohen's $d=2.260$; high $17 \beta$-estradiol: $\mathrm{p}<0.0001$, Cohen's $d=3.876$; Figure $3 B$; interaction: $\left.F_{(2,34)}=8.955, p=0.0008, \eta^{2}=0.128\right)$. There were also main effects of sex on $p p 38\left(F_{(1,34)}=45.13, p<0.0001\right.$, $\left.\eta^{2}=0.323\right)$ and $17 \beta$-estradiol $\left(F_{(2,34)}=18.54, p<0.0001, \eta^{2}=0.266\right)$. Although there was main effect of sex for $\mathrm{pERK} 1 / 2\left(\mathrm{~F}_{(1,39)}=6.067, \mathrm{p}=0.0183, \eta^{2}=0.133\right.$; Figure $\left.3 \mathrm{~B}\right)$, the vehicle treated males and females did not significantly differ ( $>>0.05)$. There were no significant effects on pJNK in the ventral DG (all ps $>0.415)$.

There were no significant sex (all ps $>0.145$ ) or $17 \beta$-estradiol (all ps $>0.134$ ) effects observed for any MAPK analyte in either the dorsal or ventral CA1 in intact males or females (Figures 3C-D).

\section{$\underline{\text { Ovariectomized females }}$}

Akt pathway: $17 \beta$-Estradiol increased Akt phosphoproteins in the CA1 region of OVX rats.

In ovariectomized rats, $17 \beta$-estradiol had more significant effects on cell signalling phosphoproteins in the hippocampus than in intact rats but these effects were largely restricted to the CA1 region. There were no significant effects of $17 \beta$-estradiol on Akt pathway phosphoproteins in the DG of OVX rats (all ps $>0.270$, Figures $4 A-B$ ). In the dorsal CA1, $17 \beta$-estradiol increased pGSK-3 $\beta$ by 34-43\%, regardless of dose (43\% increase with low $17 \beta$-estradiol: $p=0.024$, Cohen's $d=2.37$; 34\% increase with high $17 \beta$-estradiol: $p=0.032$, Cohen's $d=1.32$; main effect of $17 \beta$-estradiol: $F_{(2,13)}=4.889$, $p=0.026, \eta^{2}=0.4293$; Figure $4 \mathrm{C}$ ). However, in the ventral CA1 only the low dose of $17 \beta$-estradiol increased pAkt by 89\% ( $p=0.042$, Cohen's $d=1.397$; Figure $4 \mathrm{D})$ and $\mathrm{pGSK}-3 \beta$ by $79 \%(\mathrm{p}=0.008$, Cohen's d=1.859; Figure 4D). There were no other $17 \beta$-estradiol effects in the dorsal or ventral CA1 (all ps $>0.205)$.

\section{MAPK pathway: $17 \beta$-Estradiol increases MAPK phosphoproteins in the CA1 and DG of OVX rats}

$17 \beta$-estradiol increased pERK1/2 and pJNK activation in the dorsal DG, (pERK1/2: low 17 $\beta$ estradiol $-147 \%$ increase, $p=0.031$, Cohen's $d=1.356$; pJNK: low $17 \beta$-estradiol $-57 \%$ increase, $\mathrm{p}=0.028$, Cohen's $d=1.401$, main effect of $17 \beta$-estradiol: $\mathrm{F}^{*}{ }_{(2,6.337)}=5.56, \mathrm{p}=0.0403$; Figure $\left.5 \mathrm{~A}\right)$. There were no other significant effects of $17 \beta$-estradiol in the dorsal or ventral DG (all $\mathrm{p}>0.303$, Figure $5 B$ ).

In the dorsal CA1, both $17 \beta$-estradiol doses increased pJNK by $27 \%$ (low $17 \beta$-estradiol: $\mathrm{p}=0.017$, Cohen's $d=1.56$; high 17 $\beta$-estradiol: $p=0.009$, $d=1.89$; main effect of $17 \beta$-estradiol: $F_{(2,15)}=6.288$, $p=0.0104, \eta^{2}=0.456$; Figure $5 C$ ). There were no other significant effects on MAPK phosphoproteins in the dorsal CA1. 
In the ventral CA1, low $17 \beta$-estradiol, but not high $17 \beta$-estradiol, increased pERK1/2 by $114 \%$ and pJNK by 58\% in OVX rats (pERK1/2 - p=0.003, Cohen's $d=2.434$, main effect of $17 \beta$-estradiol: $\mathrm{F}_{(2,15)}=8.731, \mathrm{p}=0.0031, \eta^{2}=0.538 ; \mathrm{pJNK}-\mathrm{p}=0.027$, Cohen's $\mathrm{d}=1.537$, main effect of 17 $\beta$-estradiol: $F_{(2,14)}=5.64, p=0.0160, \eta^{2}=0.446$; Figure 5D). There were no other significant effects of $17 \beta$-estradiol of any MAPK phosphoproteins in the ventral CA1 (all ps>0.22).

\section{Discussion}

Past characterization of the rapid effects of estrogens on cell signaling cascades has predominantly focused on the CA1 of the dorsal hippocampus or the dorsal hippocampus as a whole and has rarely investigated sex differences. Here, we found sex differences in phosphoprotein levels in the dorsal and ventral DG and dorsal CA1 in MAPK and Akt cascades. $17 \beta$-estradiol had more dramatic effects in OVX females compared to intact females and males on MAPK and Akt pathways. In intact rats, $17 \beta$-estradiol significantly decreased MAPK phosphoproteins in females but a low dose of $17 \beta$ estradiol increased pp38 in males in the ventral DG. Dose-dependent effects of 17 $\beta$-estradiol were observed mainly in the CA1 in OVX female mice in both Akt and MAPK pathways. Collectively, these findings are the first characterization of sex differences in MAPK and Akt phosphoprotein levels across the anatomical longitudinal axis of the hippocampus in the DG and CA1. These findings illustrate that both sex and $17 \beta$-estradiol differentially influence phosphoprotein levels in region-specific ways in the hippocampus.

Sex differences in MAPK and Akt cell signalling pathways in the DG.

Consistent with investigations of other brain regions, we observed sex differences in cell signaling pathways in the dorsal and ventral DG, mostly in the Akt pathway (see Table 1 for summary). Females had higher Akt pathway phosphoproteins across the anatomical longitudinal axis and between subregions of the hippocampus than males. On the other hand, males only had higher pERK1/2 than females in the dorsal DG. These findings are partially consistent to past work in other areas of the brain, as female rats had higher baseline levels of pERK1/2, pAkt, and pGSK-3 $\beta$ in the frontal cortex (prelimbic and infralimbic cortices), nucleus accumbens, and rostral caudate putamen than males (26). Those findings, at least the Akt pathway proteins, mirrors our findings in the hippocampus. In male mice, pERK1/2 expression in the AVPV was higher, irrespective of gonad status, compared to females (28), similar to our findings in the dorsal DG. Regrettably, while much has been made of sex differences in MAPK and Akt pathway proteins in skeletal muscle, heart, and other peripheral tissues (e.g. $(46,47)$ ), these are few investigations into sex differences in MAPK or Akt signaling in the brain. Our findings suggest sex differences, favouring females, in the Akt signalling pathways across the dorsal and ventral axis of the DG of the hippocampus and with males showing greater activation of ERK1/2 in the dorsal DG.

It is intriguing that females had higher levels of Akt phosphoproteins than males in the DG, which 303 adds to the literature showing greater Akt phosphoproteins in the brain $(26,48)$ and periphery $(46)$ of females compared to males. The Akt pathway provides a mechanism through which extrinsic factors such as neurotrophic factors can activate transcription factors to affect the regulation of neural stem cells and neurogenesis in the DG (49). Recent evidence suggests that Akt pathway activation can enhance 
ischemia-induced neurogenesis and cell migration in males (50) and inactivation can attenuate the exercise-induced neurogenesis in the DG in male mice (51). The fact that the DG was the region that showed sex differences suggests that this may be involved in sex differences in neurogenesis that exist in maturation timelines (52) but also in neurogenic response to androgens (53) and stress exposure (54). Voluntary running increases neurogenesis in the DG of females more so than in males $(55,56)$, suggesting another possible mechanism for this sex difference in Akt phosphoproteins. Collectively these findings suggest that one function of the increased Akt phosphoproteins may be differences in DG neurogenesis in response to certain neurotropic factors in females compared to males. Clearly more work needs to be done to determine to determine the sex specific roles of Akt in the hippocampus.

Understanding the functional significance of these differences is perhaps more important than understanding from whence they arise. Convergent sex differences - those where the underlying cellular mechanisms differ but the behavioural outcome is similar between the sexes - have been observed now in a number of brain regions and behaviours, including spatial tasks, social learning, eye-blink learning, fear behaviors, and synaptic potentiation (57-60). Finally, these data may have implications with regards to latent sex differences; that is, sex differences that only become apparent following environmental or pharmacological interventions and/or aging/disease. For example, females are resistant to the behavioural effects of the neonatal ventral hippocampal lesion model of schizophrenia, potentially resulting from greater MEK-ERK pathway activity in the prefrontal cortex and striatum (26). Perhaps greater Akt pathway phosphoproteins present in the DG of females would make them more resilient to disruptions of this pathway. We suggest that when assessing behaviour and its underlying mechanisms that researchers pay close attention to the potential sex differences in those underlying mechanisms, especially in the case of cell signalling cascades, even when no change in behaviour is present between the sexes.

\section{$17 \beta$-estradiol on hippocampal cell signalling pathways in OVX rats}

We found more dramatic effects of $17 \beta$-estradiol on cell signalling activation in the hippocampus of OVX rats compared to intact rats (see Table 2 for summary). Estradiol rapidly increased MAPK and Akt pathway phosphoproteins dependent on dose and longitudinal axis within the CA1 region of OVX rats. It is perhaps not surprising that the CA1 region was particularly sensitive to activation of cell signalling proteins in response to $17 \beta$-estradiol as others have found that the dorsal CA1 region shows rapid upregulation of spine density and memory consolidation (27,33,34,36,61-64). Our results are consistent with Koss et al. (2018) who found that whole dorsal hippocampi of OVX female mice, but not gonadally-intact males had increased pAkt and pERK2 (p42 isoform) following acute 17 $\beta$-estradiol treatment. Although we did not see statistically significant effects in the dorsal CA1 or ventral DG, the direction of the means favours an increase in pERK1/2 with $17 \beta$-estradiol. It is important to note here that Koss and colleagues (27) saw differences in pERK only in pERK2 and not pERK1 whereas our analysis did not discriminate between isoforms. In addition to the hippocampus, estradiol rapidly increases pERK1/2 in the medial preoptic area and AVPV (28). Further, effects of $17 \beta$-estradiol on pAkt were present only in the ventral CA1 and not in the dorsal CA1, which is interesting given the functional implications of these regions. Future research should consider the anatomical longitudinal axis, as findings can differ based on this and may be important for therapeutic outcomes. 
As alluded to above, $17 \beta$-estradiol treatment increased pERK1/2 in the DG and ventral CA1 of OVX rats but not in gonadally intact male and female rats. Consistent with our findings, Koss et al (27) found that $17 \beta$-estradiol increased pERK2 in OVX female mice, and not in intact males. Much of the previous work on the rapid effects of $17 \beta$-estradiol has focused on comparing to an OVX group. However, except for pAkt in the dorsal CA1 and pp38 in the ventral DG, the effects of $17 \beta$-estradiol treatment in this study were only present in OVX rats and not intact rats. It is possible that more effects would be seen at a different (earlier) timepoint than 30 minutes (discussed below). Another possible reason is that the intracellular response to estrogens is already at ceiling in gonadally-intact female rats. While not directly compared, phosphoprotein levels (e.g. Akt analytes in the dorsal DG) in OVX rats were lower than in gonadally-intact females. Further supporting this is the inverted U-shaped dose response in OVX rats in which low $17 \beta$-estradiol increased phosphoproteins whereas high $17 \beta$-estradiol largely did not. This is frequently seen in sex steroid research $(9,65)$ and likely results from higher doses activating off target effects. As such, treatment of gonadally-intact female mice with $17 \beta$-estradiol may hormones. This has substantial implications for the conclusions and translatability of preclinical $17 \beta$ estradiol research. For example, if $17 \beta$-estradiol treatment leads to an improvement in a cognitive task in OVX rodents in a MAPK- or Akt-dependent manner, it should not be assumed that the same improvements would be seen in gonadally-intact rodents.

\section{Differences across hippocampal subregions and along the longitudinal axis}

Estrogens, in particular $17 \beta$-estradiol, affect neuroplasticity in a subregion-dependant manner in the hippocampus. For example, $17 \beta$-estradiol increases apical dendritic spine density in the dorsal CA1 $(21,25,31,61-64)$ but not in the DG $(21,31)$. However, $17 \beta$-estradiol rapidly increases cell proliferation in the dorsal and ventral DG of OVX rats $(6,30)$, with the effects on males or gonadally-intact females to be determined. Inhibition of ERK signaling blocks the increased dendritic spine densities in dorsal CA1 and medial prefrontal cortex following intrahippocampal 17 $\beta$-estradiol treatment (64). Given our findings that low $17 \beta$-estradiol increases pERK, pJNK, and pGSK-3 $\beta$ in dorsal DG, perhaps the rapid effects of $17 \beta$-estradiol on cell proliferation in the DG (6) involves activation of these phosphoproteins. As such, investigations into the intracellular mechanisms driving rapid increases in cell proliferation in

It remains possible that the other subregions of the hippocampus drive effects seen in previous studies that were absent in ours. Here, we focused on the CA1 and DG as many of the established rapid effects of estrogens occur within these regions (e.g. (6,30,61-64); for recent reviews, see $(3,9)$ ). As many hippocampus response to $17 \beta$-estradiol, are driven by hippocampal regions other than the CA1 and DG, such as the CA3 region.

\section{Estrous cycle}

In the present study, we did not observe any statistical effects of estrous cycle, although our study was not designed to specifically examine estrous cycle changes. There is a paucity of research making comparisons across the estrous cycle with regards to cell signaling cascades in the brain. One study found 
that transcription of MAPK and, potentially, Akt cascade phosphoprotein mRNA in the medial prefrontal cortex of rats was upregulated in proestrus (66). In the ventral hippocampus, chromatin dynamics and resulting MAPK pathway protein gene expression vary across the estrous cycle and between male and female mice (67). In addition to changes in dendritic spine densities in the rat hippocampus across the estrous cycle $(68,69)$, changes in total hippocampal volume across the mouse estrous cycle have been observed, with high estrogen phases associated with greater hippocampal volume (70). Similar changes have been found across the human menstrual cycle $(71,72)$. With so many neuroplastic changes occurring with natural fluctuations of estrogens, further investigations into the effects of the estrous cycle on estrogen-responsive kinase pathways are needed.

\section{Limitations and Future Directions}

One limitation is that we only examined a 30 min window after $17 \beta$-estradiol exposure. We selected a 30 min delay in the present study as others have noted changes to hippocampal physiology and behaviour have been observed at this timepoint $(6,30,64,73)$ following $17 \beta$-estradiol or shortly thereafter (e.g 40 min (61-63)). However, other studies (using intrahippocampal infusion) have found increases in many MAPK and Akt phosphoproteins in the hippocampus as early as 5-10 min following 17 $\beta$-estradiol (33-36). Due to the transient nature of phosphorylation in cell signalling cascades, it remains possible that the effects of treatment occurred at an earlier timepoint than in our study. Furthermore, it is possible that both sex and/or gonadal status may affect the rate at which these rapid effects of $17 \beta$-estradiol occur and should be investigated further.

The present data were normalized to total protein in sample (as is done in regularly in the literature: (39,43-45), for example). One possible limitation is that phosphorylated proteins were not normalised to the specific protein under investigation (e.g. pERK1/2 normalized to total ERK1/2). It remains possible that there are sex differences in and estradiol effects on total protein levels that could confound the interpretation of the present results. Genomic synthesis of novel MAPK, Akt, or other proteins triggered by $17 \beta$-estradiol is unlikely due to the time of tissue collection (30 min). It remains possible, however, that $17 \beta$-estradiol could rapidly increase the total protein levels via non-genomic mechanisms, such as the translation of mRNA transcripts already in the cell. Additionally, it is through the phosphorylation of these proteins that functional outcomes occur (e.g. DNA transcription, protein translation, actin polymerization, etc.), thus obtaining the functional unit of these pathways.

The electrochemiluminescent assay is highly sensitive and selective, provides quantitative data for analyses, and requires relatively little tissue for analysis compared to similar assays $(41,42)$. Other cell signaling cascades or proteins, such as the eukaryotic translation initiation factor 4E-binding protein 1, a translation repressor protein downstream of many Akt and MAPK phosphoproteins including Akt, ERK1/2, and p38 (74) would be important proteins to examine in the future. Estradiol only had significant effects on phosphoprotein level in the ventral DG where pp38 was decreased in female rats only. This reduction could result from inactivation by upstream kinases or as a compensatory mechanism following transient activation (75), which would be important to examine in the future. In addition, in the present study we focussed on the CA1 and DG as they are rapidly affected by estrogens (9). However, the CA3 is an additional region of interest, given sex and estradiol differences in morphology and response to stress in this region $(20,68,76)$. 
Sex differences in MAPK and Akt cell signaling phosphoproteins exist in both the dorsal and ventral DG in rats. Estradiol treatment increased MAPK and Akt signaling in the CA1 and dorsal DG in OVX rats with far fewer effects in intact females or males. These results shed light on the possible underlying mechanisms of sex differences in hippocampal function in response to $17 \beta$-estradiol that affect MAPK and Akt kinase pathways. They further show the heterogeneity of estrogen and sex effects between hippocampal subregions and along the dorsal/ventral axis. With these subregions serving often distinct purposes, and the functional dissociation between the dorsal and ventral hippocampus, the present results provide possible mechanisms through which these differences may arise. Furthermore, with many neurological disorders having profound effects on the hippocampus, these sex, hormonal status, and regional differences provide valuable insights not only into the potential underlying mechanisms, but also into therapeutic possibilities.

\section{Acknowledgements}

446 The authors would like to thank Stephanie Lieblich for her assistance with surgeries, Dr. Rand Eid for her guidance and assistance with the electrochemiluminescence assays, Muna Ibrahim and Rebecca Rechlin for estrous cycle determination, and the staff at the Centre for Disease Modeling at the University of British Columbia for their ongoing care for and kindness towards the animals in that facility.

452 All experiments were conducted in accordance with the ethical guidelines set by the Canada Council for 453 Animal Care and were approved by the University of British Columbia Animal Care Committee. All efforts were made to reduce the number and the suffering of animals.

\section{Conflicts of Interest}

457 The authors have no conflicts of interest to declare.

\section{Funding Sources}

460 This research was funded by Natural Sciences and Engineering Research Council of Canada grants to LAMG (RGPIN-2018-04301 and RGPAS-2018-522454).

\section{Author Contributions}

464 PASS - conception and design of the work; data acquisition, analysis, and interpretation; writing and 465 revising

466 TAP - conception and design of the work; data acquisition, analysis, and interpretation; writing and 467 revising

468 LAMG - conception and design of the work; data acquisition, analysis, and interpretation; writing and 469 revising

470

472 All data is available upon request to corresponding author. 
473

474

475

476

477

478

479

480

481

482

483

484

485

486

487

488

489

490

491

492

493

494

495

496

497

498

499

500

501

502

503

1. Frick KM. Molecular mechanisms underlying the memory-enhancing effects of estradiol. Horm Behav. 2015 Aug;74:4-18.

2. Sheppard PAS, Koss WA, Frick KM, Choleris E. Rapid actions of oestrogens and their receptors on memory acquisition and consolidation in females. J Neuroendocrinol. 2018 Feb;30(2):e12485.

3. Taxier LR, Gross KS, Frick KM. Oestradiol as a neuromodulator of learning and memory. Nat Rev Neurosci. 2020 Oct;21(10):535-50.

4. Paletta P, Sheppard PAS, Matta R, Ervin KSJ, Choleris E. Rapid effects of estrogens on short-term memory: Possible mechanisms. Horm Behav. 2018 Aug;104:88-99.

5. Zurkovsky L, Serio SJ, Korol DL. Intra-striatal estradiol in female rats impairs response learning within two hours of treatment. Horm Behav. 2011 Nov;60(5):470-7.

6. Barha CK, Lieblich SE, Galea L a. M. Different Forms of Oestrogen Rapidly Upregulate Cell Proliferation in the Dentate Gyrus of Adult Female Rats. J Neuroendocrinol. 2009;21(3):155-66.

7. Sellers K, Raval P, Srivastava DP. Molecular signature of rapid estrogen regulation of synaptic connectivity and cognition. Front Neuroendocrinol. 2015 Jan 1;36:72-89.

8. Sellers KJ, Erli F, Raval P, Watson IA, Chen D, Srivastava DP. Rapid modulation of synaptogenesis and spinogenesis by 17 $\beta$-estradiol in primary cortical neurons. Front Cell Neurosci. 2015;9:137.

9. Sheppard PAS, Choleris E, Galea LAM. Structural plasticity of the hippocampus in response to estrogens in female rodents. Mol Brain. 2019 Mar 18;12(1):22.

10. Nilsson S, Mäkelä S, Treuter E, Tujague M, Thomsen J, Andersson G, et al. Mechanisms of estrogen action. Physiol Rev. 2001 Oct;81(4):1535-65.

11. Lai Y-J, Yu D, Zhang JH, Chen G-J. Cooperation of genomic and rapid nongenomic actions of estrogens in synaptic plasticity. Mol Neurobiol. 2017;54(6):4113-26.

12. Marshall CJ. MAP kinase kinase kinase, MAP kinase kinase and MAP kinase. Curr Opin Genet Dev. 1994 Feb;4(1):82-9.

13. Seger R, Krebs EG. The MAPK signaling cascade. FASEB J. 1995 Jun;9(9):726-35.

14. Manning BD, Cantley LC. AKT/PKB signaling: Navigating downstream. Cell. 2007 Jun 29;129(7):1261-74.

15. Dorard C, Vucak G, Baccarini M. Deciphering the RAS/ERK pathway in vivo. Biochem Soc Trans. 2017 Feb 8;45(1):27-36.

16. Cao Z, Liao Q, Su M, Huang K, Jin J, Cao D. AKT and ERK dual inhibitors: The way forward? Cancer Lett. 2019 Sep 10;459:30-40. 
bioRxiv preprint doi: https://doi.org/10.1101/2021.05.30.446341; this version posted July 29, 2021. The copyright holder for this preprint (which was not certified by peer review) is the author/funder, who has granted bioRxiv a license to display the preprint in perpetuity. It is made available under aCC-BY-NC-ND 4.0 International license.

504

505

506

507

508

509

510

511

512

513

514

515

516

517

518

519

520

521

522

523

524

525

526

527

528

529

530

531

532

533

534

535

536

537

538

539

17. Titolo D, Mayer CM, Dhillon SS, Cai F, Belsham DD. Estrogen facilitates both phosphatidylinositol 3-kinase/Akt and ERK1/2 mitogen-activated protein kinase membrane signaling required for long-term neuropeptide $Y$ transcriptional regulation in clonal, immortalized neurons. J Neurosci. 2008 Jun $18 ; 28(25): 6473-82$.

18. Winter JN, Jefferson LS, Kimball SR. ERK and Akt signaling pathways function through parallel mechanisms to promote mTORC1 signaling. Am J Physiol - Cell Physiol. 2011 May;300(5):C117280.

19. Zhou J, Du T, Li B, Rong Y, Verkhratsky A, Peng L. Crosstalk between MAPK/ERK and PI3K/AKT signal pathways during brain ischemia/reperfusion. ASN NEURO. 2015 Oct 6;7(5): 1759091415602463.

20. Miranda P, Williams CL, Einstein G. Granule cells in aging rats are sexually dimorphic in their response to estradiol. J Neurosci. 1999 May 1;19(9):3316-25.

21. Gould E, Woolley CS, Frankfurt M, McEwen BS. Gonadal steroids regulate dendritic spine density in hippocampal pyramidal cells in adulthood. J Neurosci. 1990 Apr;10(4):1286-91.

22. Leranth C, Petnehazy O, MacLusky NJ. Gonadal hormones affect spine synaptic density in the CA1 hippocampal subfield of male rats. J Neurosci. 2003 Mar 1;23(5):1588-92.

23. Wallace $M$, Luine V, Arellanos A, Frankfurt M. Ovariectomized rats show decreased recognition memory and spine density in the hippocampus and prefrontal cortex. Brain Res. 2006 Dec 18;1126(1):176-82.

24. MacLusky NJ, Luine VN, Hajszan T, Leranth C. The 17alpha and 17beta isomers of estradiol both induce rapid spine synapse formation in the CA1 hippocampal subfield of ovariectomized female rats. Endocrinology. 2005 Jan;146(1):287-93.

25. Woolley CS, McEwen BS. Roles of estradiol and progesterone in regulation of hippocampal dendritic spine density during the estrous cycle in the rat. J Comp Neurol. 1993 Oct 8;336(2):293-306.

26. Bychkov E, Ahmed MR, Gurevich EV. Sex differences in the activity of signalling pathways and expression of G-protein-coupled receptor kinases in the neonatal ventral hippocampal lesion model of schizophrenia. Int J Neuropsychopharmacol. 2011 Feb;14(1):1-15.

27. Koss WA, Haertel JM, Philippi SM, Frick KM. Sex differences in the rapid cell signaling mechanisms underlying the memory-enhancing effects of $17 \beta$-estradiol. eNeuro. 2018 Oct 16;5(5):e0267-18.2018.

28. Barabás K, Szegõ ÉM, Kaszás A, Nagy GM, Juhász GD, Ábrahám IM. Sex Differences in oestrogeninduced p44/42 MAPK phosphorylation in the mouse brain in vivo. J Neuroendocrinol. 2006 Aug 1;18(8):621-8.

29. Fanselow MS, Dong H-W. Are the dorsal and ventral hippocampus functionally distinct structures? Neuron. 2010 Jan 14;65(1):7-19. 
bioRxiv preprint doi: https://doi.org/10.1101/2021.05.30.446341; this version posted July 29, 2021. The copyright holder for this preprint (which was not certified by peer review) is the author/funder, who has granted bioRxiv a license to display the preprint in perpetuity. It is made available under aCC-BY-NC-ND 4.0 International license.

540

541

542

543

544

545

546

547

548

549

550

551

552

553

554

555

556

557

558

559

560

561

562

563

564

565

566

567

568

569

570

571

572

573

574

30. Duarte-Guterman P, Lieblich SE, Chow C, Galea LAM. Estradiol and GPER activation differentially affect cell proliferation but not GPER expression in the hippocampus of adult female rats. PLoS One. 2015;10(6):e0129880.

31. Jacome LF, Barateli K, Buitrago D, Lema F, Frankfurt M, Luine VN. Gonadal hormones rapidly enhance spatial memory and increase hippocampal spine density in male rats. Endocrinology. 2016 Apr 1;157(4):1357-62.

32. Cardona-Gomez P, Perez M, Avila J, Garcia-Segura LM, Wandosell F. Estradiol inhibits GSK3 and regulates interaction of estrogen receptors, GSK3, and beta-catenin in the hippocampus. Mol Cell Neurosci. 2004 Mar 1;25(3):363-73.

33. Fan L, Zhao Z, Orr PT, Chambers CH, Lewis MC, Frick KM. Estradiol-induced object memory consolidation in middle-aged female mice requires dorsal hippocampal extracellular signalregulated kinase and phosphatidylinositol 3-kinase activation. J Neurosci. 2010 Mar 24;30(12):4390-400.

34. Fortress AM, Fan L, Orr PT, Zhao Z, Frick KM. Estradiol-induced object recognition memory consolidation is dependent on activation of mTOR signaling in the dorsal hippocampus. Learn Mem. 2013 Feb 19;20(3):147-55.

35. Kim J, Szinte JS, Boulware MI, Frick KM. 17ß-estradiol and agonism of G-protein-coupled estrogen receptor enhance hippocampal memory via different cell-signaling mechanisms. J Neurosci. 2016 Mar 16;36(11):3309-21.

36. Fernandez SM, Lewis MC, Pechenino AS, Harburger LL, Orr PT, Gresack JE, et al. Estradiolinduced enhancement of object memory consolidation involves hippocampal extracellular signal-regulated kinase activation and membrane-bound estrogen receptors. J Neurosci. 2008 Aug 27;28(35):8660-7.

37. Pinceti E, Shults CL, Rao YS, Pak TR. Differential effects of E2 on MAPK activity in the brain and heart of aged female rats. PLoS ONE. 2016 Aug 3;11(8):e0160276.

38. Cora MC, Kooistra L, Travlos G. Vaginal cytology of the laboratory rat and mouse: Review and criteria for the staging of the estrous cycle using stained vaginal smears. Toxicol Pathol. 2015 Aug 1;43(6):776-93.

39. Eid RS, Lieblich SE, Wong SJ, Galea LAM. Ovarian status dictates the neuroinflammatory and behavioral consequences of sub-chronic stress exposure in middle-aged female mice. Neurobiol Stress. 2019 Nov 20;12:100199.

40. Viau V, Meaney MJ. Variations in the hypothalamic-pituitary-adrenal response to stress during the estrous cycle in the rat. Endocrinology. 1991 Nov;129(5):2503-11.

41. Chen M, Ning Z, Chen K, Zhang Y, Shen Y. Recent advances of electrochemiluminescent system in bioassay. J Anal Test. 2020 Apr 1;4(2):57-75. 
bioRxiv preprint doi: https://doi.org/10.1101/2021.05.30.446341; this version posted July 29, 2021. The copyright holder for this preprint (which was not certified by peer review) is the author/funder, who has granted bioRxiv a license to display the preprint in perpetuity. It is made available under aCC-BY-NC-ND 4.0 International license.

575

576

577

578

579

580

581

582

583

584

585

586

587

588

589

590

591

592

593

594

595

596

597

598

599

600

601

602

603

604

605

606

607

608

609

610

42. Zanut A, Fiorani A, Canola S, Saito T, Ziebart N, Rapino S, et al. Insights into the mechanism of coreactant electrochemiluminescence facilitating enhanced bioanalytical performance. Nat Commun. 2020 May 29;11(1):2668.

43. Zaworski P, Herrmann KM von, Taylor S, Sunshine SS, McCarthy K, Risher N, et al. SMN protein can be reliably measured in whole blood with an electrochemiluminescence (ECL) immunoassay: Implications for clinical trials. PLoS ONE. 2016 Mar 8;11(3):e0150640.

44. Bass V, Gordon CJ, Jarema KA, MacPhail RC, Cascio WE, Phillips PM, et al. Ozone induces glucose intolerance and systemic metabolic effects in young and aged brown Norway rats. Toxicol Appl Pharmacol. 2013 Dec 15;273(3):551-60.

45. Aldridge GM, Podrebarac DM, Greenough WT, Weiler IJ. The use of total protein stains as loading controls: an alternative to high-abundance single protein controls in semi-quantitative immunoblotting. J Neurosci Methods. 2008 Jul 30;172(2):250-4.

46. Camper-Kirby Dreama, Welch Sara, Walker Angela, Shiraishi Isao, Setchell Kenneth D. R., Schaefer Erik, et al. Myocardial Akt activation and gender. Circ Res. 2001 May 25;88(10):1020-7.

47. Nicoll JX, Fry AC, Mosier EM. Sex-based differences in resting MAPK, androgen, and glucocorticoid receptor phosphorylation in human skeletal muscle. Steroids. 2019 Jan;141:23-9.

48. Wong H, Levenga J, LaPlante L, Keller B, Cooper-Sansone A, Borski C, et al. Isoform-specific roles for AKT in affective behavior, spatial memory, and extinction related to psychiatric disorders. eLife. 2020 Dec 16;9:e56630.

49. Otaegi G, Yusta-Boyo MJ, Vergaño-Vera E, Méndez-Gómez HR, Carrera AC, Abad JL, et al. Modulation of the PI 3-kinase-Akt signalling pathway by IGF-I and PTEN regulates the differentiation of neural stem/precursor cells. J Cell Sci. 2006 Jul 1;119(13):2739-48.

50. Shioda N, Han F, Morioka M, Fukunaga K. Bis(1-oxy-2-pyridinethiolato)oxovanadium(IV) enhances neurogenesis via phosphatidylinositol 3-kinase/Akt and extracellular signal regulated kinase activation in the hippocampal subgranular zone after mouse focal cerebral ischemia. Neuroscience. 2008 Aug 26;155(3):876-87.

51. Sun L, Cui K, Xing F, Liu X. Akt dependent adult hippocampal neurogenesis regulates the behavioral improvement of treadmill running to mice model of post-traumatic stress disorder. Behav Brain Res. 2020 Feb 3;379:112375.

52. Yagi S, Splinter JEJ, Tai D, Wong S, Wen Y, Galea LAM. Sex differences in maturation and attrition of adult neurogenesis in the hippocampus. eNeuro. 2020 Jul-Aug;7(4):e0468-19.2020

53. Duarte-Guterman P, Lieblich SE, Wainwright SR, Chow C, Chaiton JA, Watson NV, et al. Androgens enhance adult hippocampal neurogenesis in males but not females in an agedependent manner. Endocrinology. 2019 Sep 1;160(9):2128-36.

54. Falconer EM, Galea LAM. Sex differences in cell proliferation, cell death and defensive behavior following acute predator odor stress in adult rats. Brain Res. 2003 Jun 13;975(1-2):22-36. 
bioRxiv preprint doi: https://doi.org/10.1101/2021.05.30.446341; this version posted July 29, 2021. The copyright holder for this preprint (which was not certified by peer review) is the author/funder, who has granted bioRxiv a license to display the preprint in perpetuity. It is made available under aCC-BY-NC-ND 4.0 International license.

624

625

626

627

628

629

630

631

632

633

634

635

636

637

638

639

640

641

642

643

644 645

55. Cahill SP, Cole JD, Yu RQ, Clemans-Gibbon J, Snyder JS. Differential effects of extended exercise and memantine treatment on adult neurogenesis in male and female rats. Neuroscience. 2018 Oct 15;390:241-55.

56. Ma X, Hamadeh MJ, Christie BR, Foster JA, Tarnopolsky MA. Impact of treadmill running and sex on hippocampal neurogenesis in the mouse model of amyotrophic lateral sclerosis. PLoS ONE. 2012 Apr 25;7(4):e36048.

57. Shors TJ, Chua C, Falduto J. Sex differences and opposite effects of stress on dendritic spine density in the male versus female hippocampus. J Neurosci. 2001 Aug 15;21(16):6292-7.

58. Choleris E, Galea LAM, Sohrabji F, Frick KM. Sex differences in the brain: Implications for behavioral and biomedical research. Neurosci Biobehav Rev. 2018;85:126-45.

59. Jain A, Huang GZ, Woolley CS. Latent sex differences in molecular signaling that underlies excitatory synaptic potentiation in the hippocampus. J Neurosci. 2019 Feb 27;39(9):1552-65.

60. Gruene TM, Roberts E, Thomas V, Ronzio A, Shansky RM. Sex-specific neuroanatomical correlates of fear expression in prefrontal-amygdala circuits. Biol Psychiatry. 2015 Aug 1;78(3):186-93.

61. Phan A, Suschkov S, Molinaro L, Reynolds K, Lymer JM, Bailey CDC, et al. Rapid increases in immature synapses parallel estrogen-induced hippocampal learning enhancements. Proc Natl Acad Sci U S A. 2015 Dec 29;112(52):16018-23.

62. Phan A, Gabor CS, Favaro KJ, Kaschack S, Armstrong JN, MacLusky NJ, et al. Low doses of 17ßestradiol rapidly improve learning and increase hippocampal dendritic spines. Neuropsychopharmacol. 2012 Sep;37(10):2299-309.

63. Sheppard PAS, Asling HA, Walczyk-Mooradally A, Armstrong SE, Elad VM, Lalonde J, et al. Protein synthesis and actin polymerization in the rapid effects of $17 \beta$-estradiol on short-term social memory and dendritic spine dynamics in female mice. Psychoneuroendocrinology. $2021 \mathrm{Apr}$ $15 ; 105232$.

64. Tuscher JJ, Luine V, Frankfurt M, Frick KM. Estradiol-mediated spine changes in the dorsal hippocampus and medial prefrontal cortex of ovariectomized female mice depend on ERK and mTOR activation in the dorsal hippocampus. J Neurosci. 2016 Feb 3;36(5):1483-9.

65. Luine VN. Estradiol and cognitive function: Past, present and future. Horm Behav. 2014 Sep 1;66(4):602-18.

66. Duclot F, Kabbaj $M$. The estrous cycle surpasses sex differences in regulating the transcriptome in the rat medial prefrontal cortex and reveals an underlying role of early growth response 1. Genome Biol. 2015 Dec 2;16(1):256.

67. Jaric I, Rocks D, Greally JM, Suzuki M, Kundakovic M. Chromatin organization in the female mouse brain fluctuates across the oestrous cycle. Nat Commun. 2019 Jun 28;10(1):2851. 
646

647

648

649

650

651

652

653

654

655

656

657

658

659

660

661

662

663

664

665

666

667

668
68. Mendell AL, Atwi S, Bailey CDC, McCloskey D, Scharfman HE, MacLusky NJ. Expansion of mossy fibers and CA3 apical dendritic length accompanies the fall in dendritic spine density after gonadectomy in male, but not female, rats. Brain Struct Funct. 2017 Jan;222(1):587-601.

69. Woolley CS, Gould E, Frankfurt M, McEwen BS. Naturally occurring fluctuation in dendritic spine density on adult hippocampal pyramidal neurons. J Neurosci. 1990 Dec;10(12):4035-9.

70. Qiu LR, Germann J, Spring S, Alm C, Vousden DA, Palmert MR, et al. Hippocampal volumes differ across the mouse estrous cycle, can change within 24hours, and associate with cognitive strategies. Neurolmage. 2013 Dec 1;83:593-8.

71. Lisofsky N, Mårtensson J, Eckert A, Lindenberger U, Gallinat J, Kühn S. Hippocampal volume and functional connectivity changes during the female menstrual cycle. Neurolmage. $2015 \mathrm{Sep}$ 1;118:154-62.

72. Pletzer B, Harris T, Hidalgo-Lopez E. Subcortical structural changes along the menstrual cycle: Beyond the hippocampus. Sci Rep. 2018 Oct 30;8: 16042.

73. Barha CK, Galea LAM. Influence of different estrogens on neuroplasticity and cognition in the hippocampus. Biochim Biophys Acta BBA - Gen Subj. 2010 Oct 1;1800(10):1056-67.

74. Qin X, Jiang B, Zhang Y. 4E-BP1, a multifactor regulated multifunctional protein. Cell Cycle. 2016 Feb 22;15(6):781-6.

75. Cuenda A, Rousseau S. p38 MAP-Kinases pathway regulation, function and role in human diseases. Biochim Biophys Acta BBA - Mol Cell Res. 2007 Aug 1;1773(8):1358-75.

76. Galea LA, McEwen BS, Tanapat P, Deak T, Spencer RL, Dhabhar FS. Sex differences in dendritic atrophy of CA3 pyramidal neurons in response to chronic restraint stress. Neuroscience. 1997 Dec;81(3):689-97. 
bioRxiv preprint doi: https://doi.org/10.1101/2021.05.30.446341; this version posted July 29, 2021. The copyright holder for this preprint (which

was not certified by peer review) is the author/funder, who has granted bioRxiv a license to display the preprint in perpetuity. It is made available under aCC-BY-NC-ND 4.0 International license.

669

670

671

672

673

674

675

676

677

678

679

680

681

682

683

684

685

686

687

688

689

690

691

692

693

694

695

696

697

698

699

700

701

702

703

704

705

706

707

708

709

\section{Figure 1: Example of CA1 and dentate gyrus punch location}

Blue circles indicate approximate CA1 tissue punch location. Red circles indicate approximate dentate gyrus tissue punch location. Punches were $0.838 \mathrm{~mm}$ in diameter.

\section{Figure 2: Akt phosphoprotein levels in the dentate gyrus (DG) and CA1 of female and male rats} Phosphoprotein signal normalized by amount of total protein in sample. A) Phosphoprotein levels were higher in females in all analytes in the dorsal DG (pAkt, pGSK-3 $\beta$, and pp70S6K: $<<0.0001)$. B)

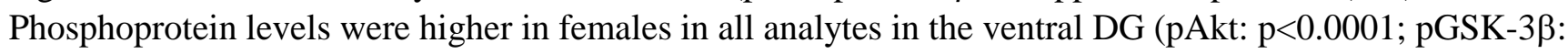
$\mathrm{p}=0.0004$; pp70S6K: $\mathrm{p}=0.0014$ ). C) High 17 $\beta$-estradiol increased dorsal CA1 pAkt in females ( $\mathrm{p}=0.05)$. There were no effects of sex between vehicle-treated rats. D) There were no effects of sex or treatment on Akt analytes in the ventral CA1. Error bars are \pm standard error of the mean. Main effects of sex: \#\# $\mathrm{p}<0.01$, \#\#\# p<0.001, \#\#\#\# p<0.0001; effects of $17 \beta$-estradiol: * $\mathrm{p}=0.05$.

Figure 3: MAPK phosphoprotein levels the dentate gyrus (DG) and CA1 of in female and male rats Phosphoprotein signal normalized by amount of total protein in sample. A) Males had higher pERK1/2 $(\mathrm{p}<0.0001)$ in the dorsal DG than females. There were no significant effects of sex among vehicle-treated rats in the dorsal DG for $\mathrm{pJNK}$ or pp38. B) In the ventral DG, there were no significant effects of sex among vehicle-treated rats. Low $17 \beta$-estradiol reduced ventral DG pp38 in females $(\mathrm{p}<0.0001)$, with high $17 \beta$-estradiol reducing pp38 still further (compared to vehicle, $\mathrm{p}<0.0001$; compared to low $17 \beta$-estradiol $\mathrm{p}<0.01$ ). C-D) There were no significant effects of sex or treatment on MAPK analytes in the dorsal CA1 (C) or the ventral CA1 (D). Error bars are \pm standard error of the mean. Main effects of sex: \#\#\#\# $\mathrm{p}<0.0001$; effects of $17 \beta$-estradiol: $* * \mathrm{p}<0.01, * * * * \mathrm{p}<0.0001$.

Figure 4: Akt phosphoprotein levels in the dentate gyrus (DG) and CA1 of ovariectomized female rats Phosphoprotein signal normalized by amount of total protein in sample. A-B) $17 \beta$-estradiol did not affect Akt pathway phosphoprotein levels in the dorsal DG (A) or ventral DG (B) of OVX rats (ps $>0.27)$ C) Low $(\mathrm{p}=0.0113)$ and high $(\mathrm{p}=0.0306) 17 \beta$-estradiol increased $\mathrm{pGSK}-3 \beta$ in the dorsal CA1. D) In the ventral CA1, low $17 \beta$-estradiol increased pAkt (relative to vehicle [p=0.0142] and high 17 $\beta$-estradiol [ $\mathrm{p}=0.0471]$ ) and pGSK-3 $\beta$ ( $\mathrm{p}=0.0025)$. Error bars are \pm standard error of the mean SEM. Effects of $17 \beta$-estradiol: * $\mathrm{p}<0.05, * * \mathrm{p}<0.01$.

Figure 5: MAPK phosphoprotein levels in the dentate gyrus (DG) and CA1 of ovariectomized female rats

Phosphoprotein signal normalized by amount of total protein in sample. A) Low 17 $\beta$-estradiol increased pERK ( $\mathrm{p}=0.031)$ and $\mathrm{pJNK}(\mathrm{p}=0.028)$ in the dorsal DG of OVX rats. B) $17 \beta$-estradiol did not affect MAPK pathway phosphoprotein levels in the ventral DG of OVX rats ( $p s>0.303)$. C) Low $(p=0.017)$ and high $(p=0.009) 17 \beta$-estradiol increased pJNK in the dorsal CA1 of OVX rats. D) In the ventral CA1, low $17 \beta$ estradiol increased $\mathrm{pERK} 1 / 2$ (relative to vehicle $[\mathrm{p}<0.01$ ] and high $17 \beta$-estradiol $[\mathrm{p}<0.05]$ ) and $\mathrm{pJNK}$ (relative to vehicle and high $17 \beta$-estradiol, ps $<0.05$ ). Error bars are \pm standard error of the mean. Effects of $17 \beta$-estradiol: $* \mathrm{p}<0.05, * * \mathrm{p}<0.01$. 
bioRxiv preprint doi: https://doi.org/10.1101/2021.05.30.446341; this version posted July 29, 2021. The copyright holder for this preprint (which was not certified by peer review) is the author/funder, who has granted bioRxiv a license to display the preprint in perpetuity. It is made available under aCC-BY-NC-ND 4.0 International license.
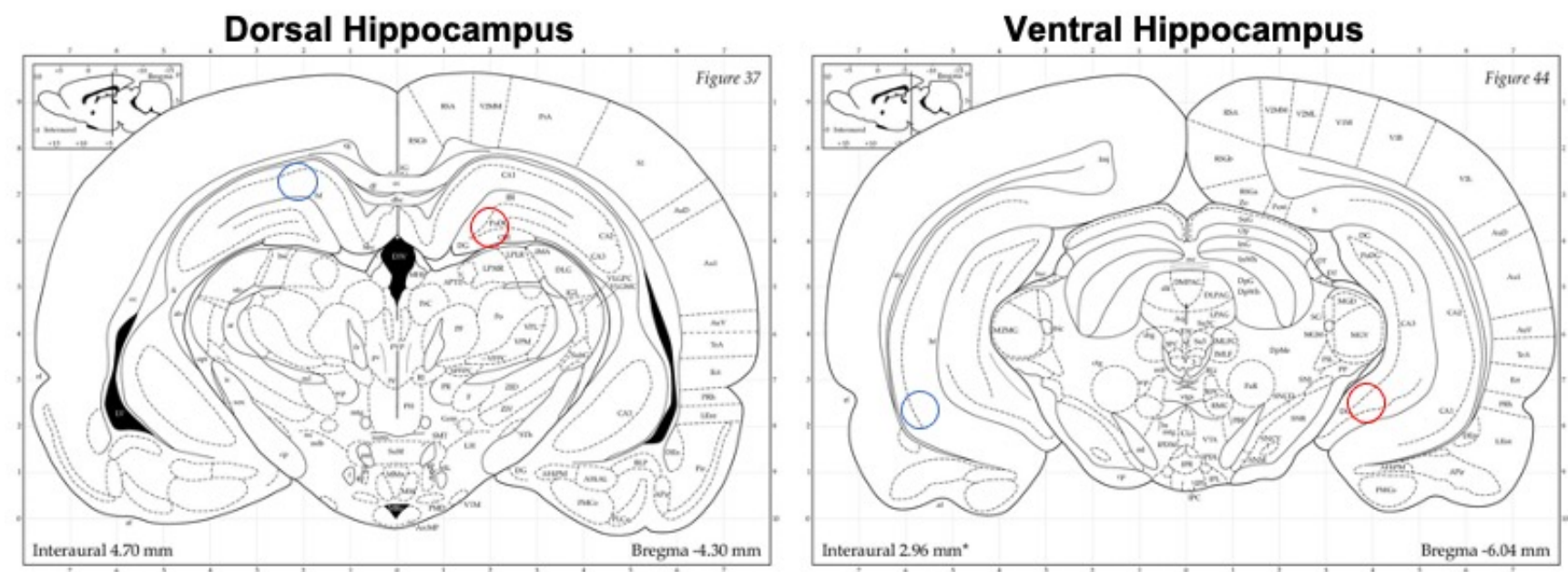

710 
A

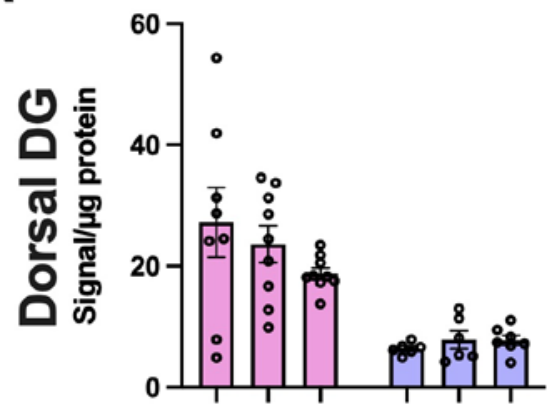

B
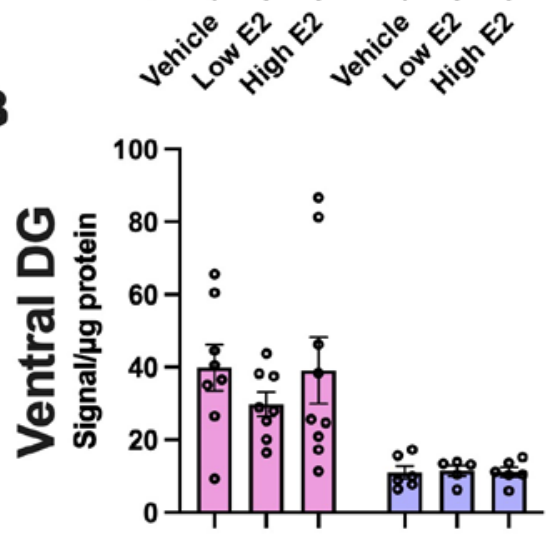

C
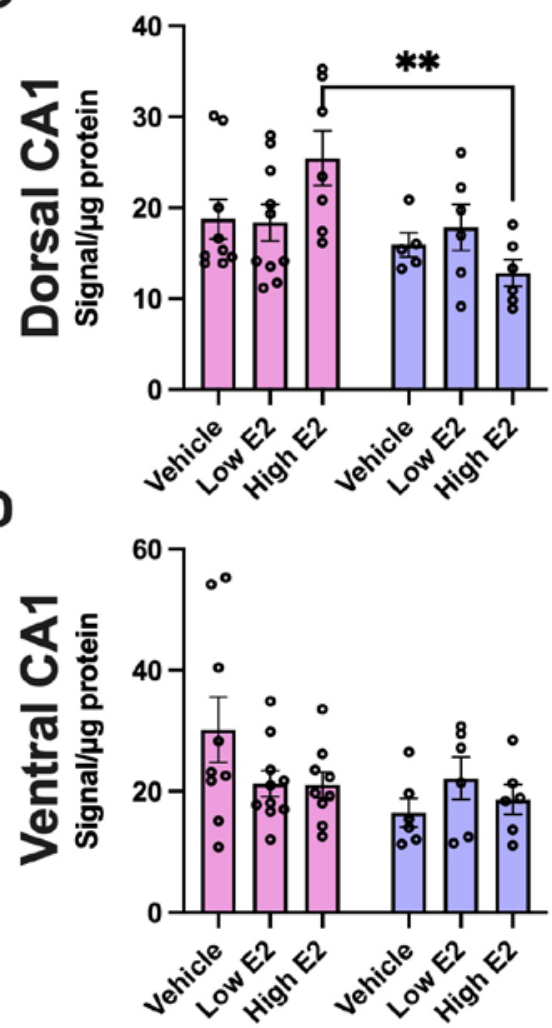

Akt Pathway_Analytes

pGSK-3 $\beta$
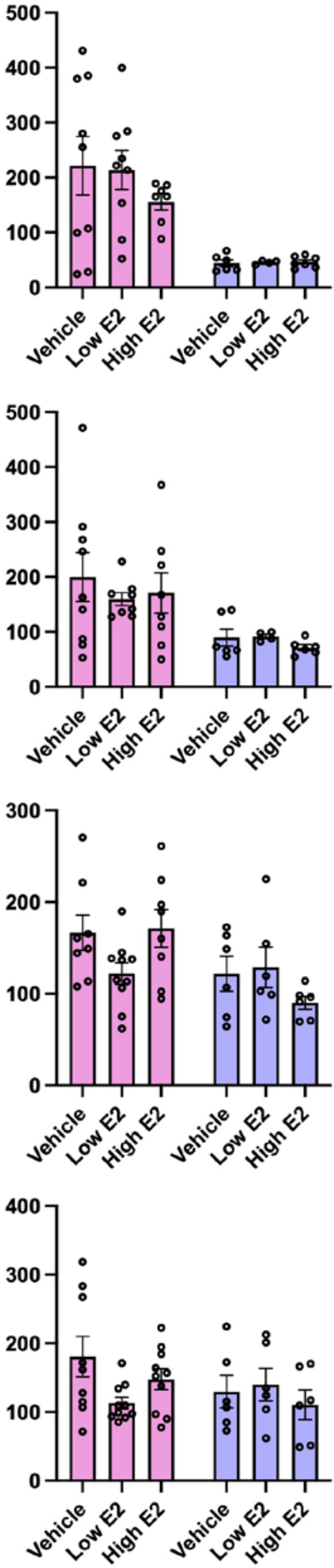
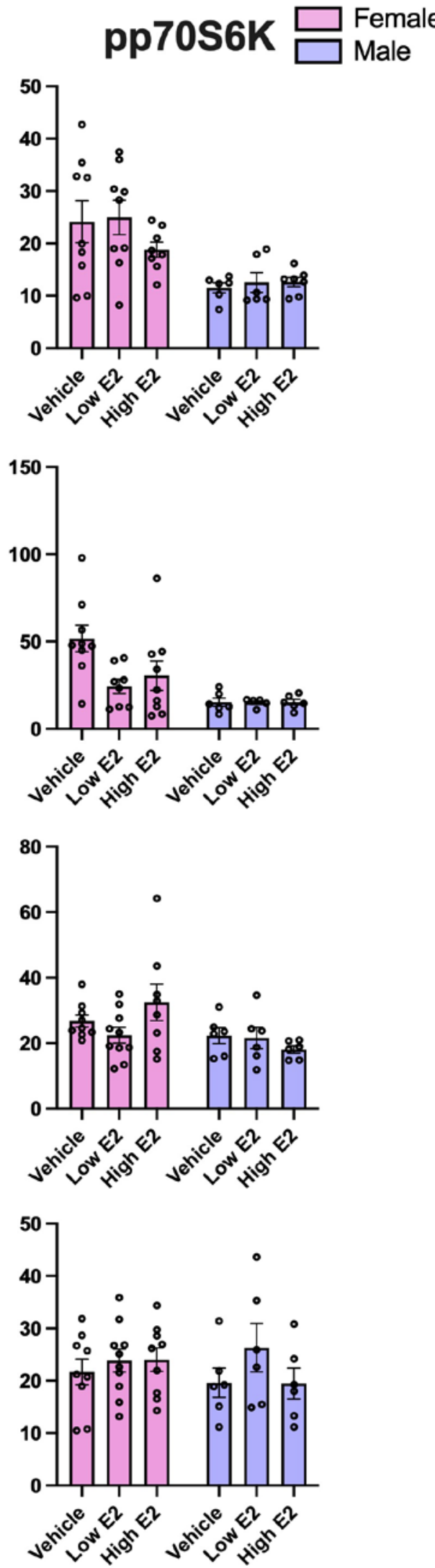
A

B

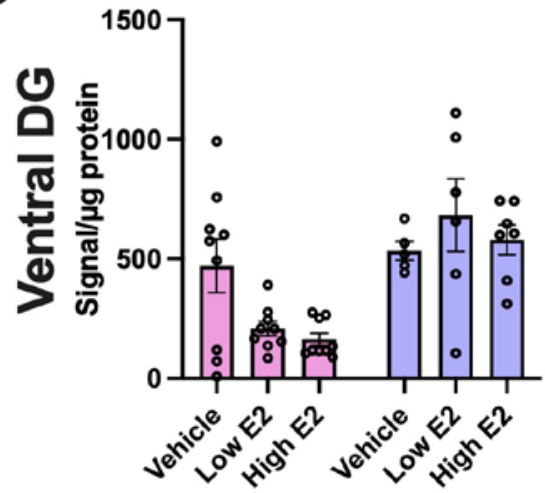

C

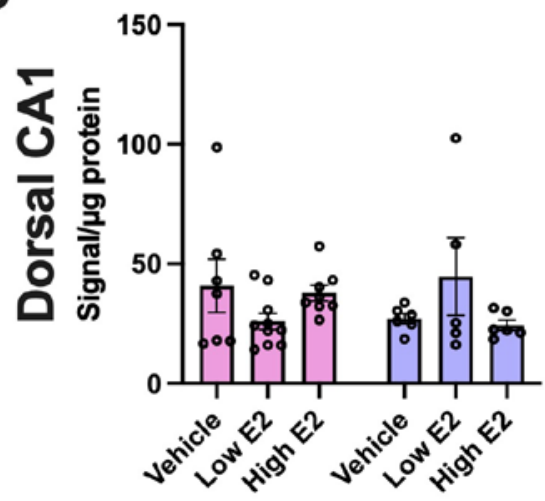

D

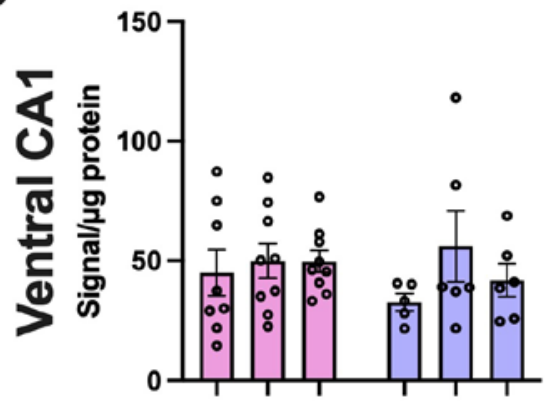

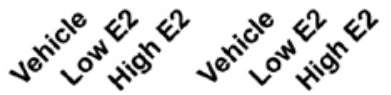

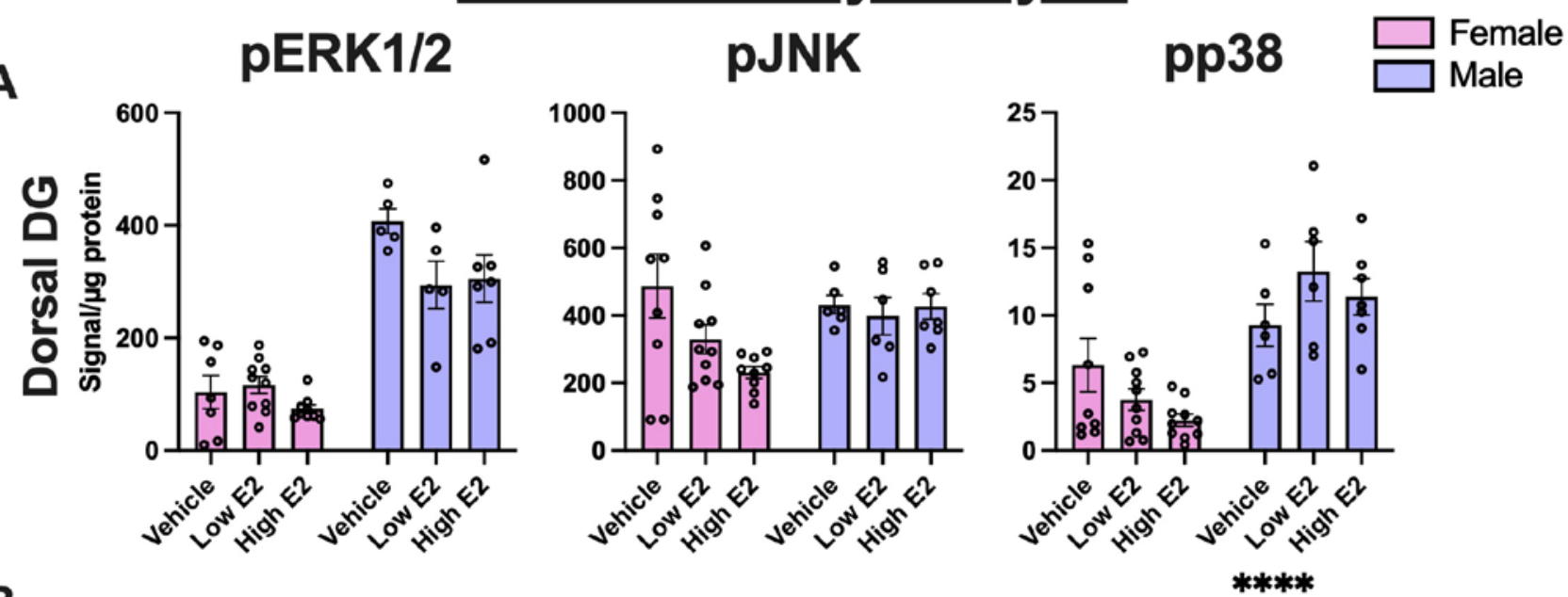

MAPK Pathway Analytes
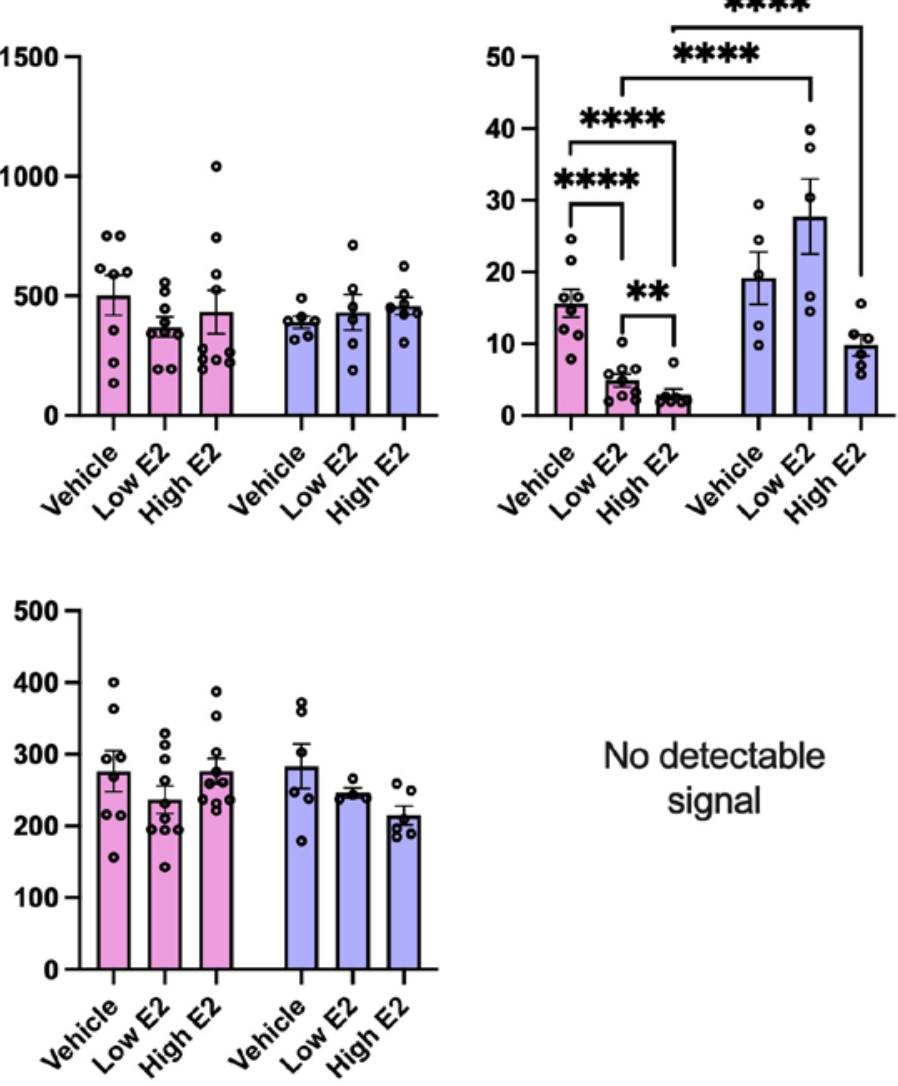

No detectable signal
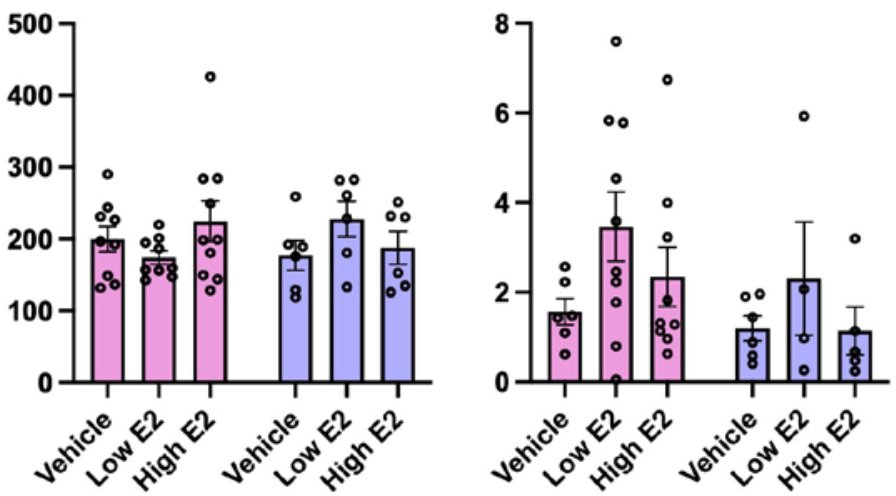


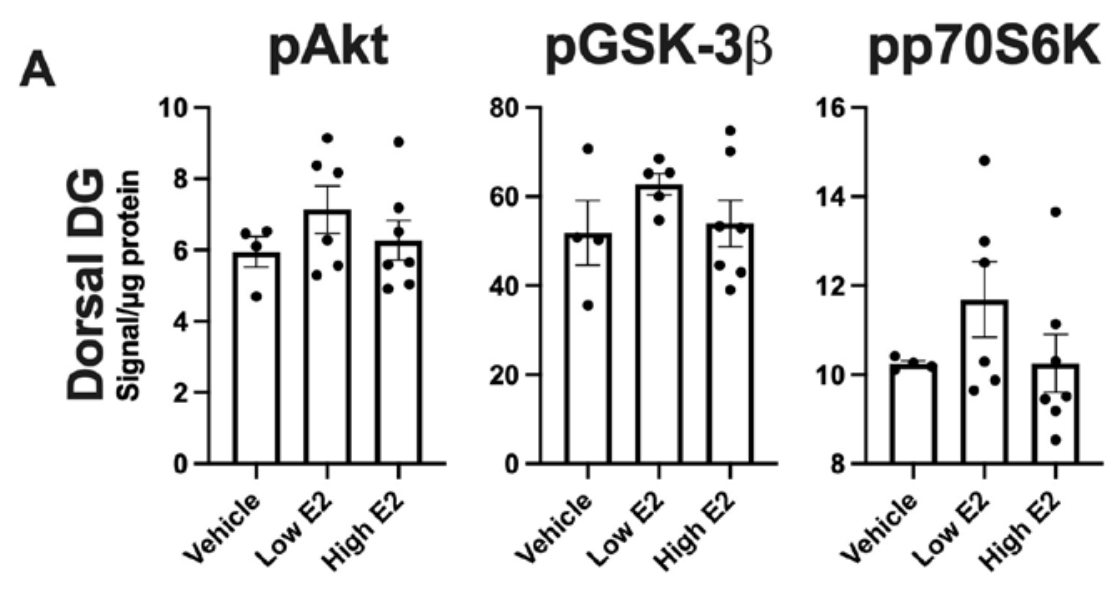

B
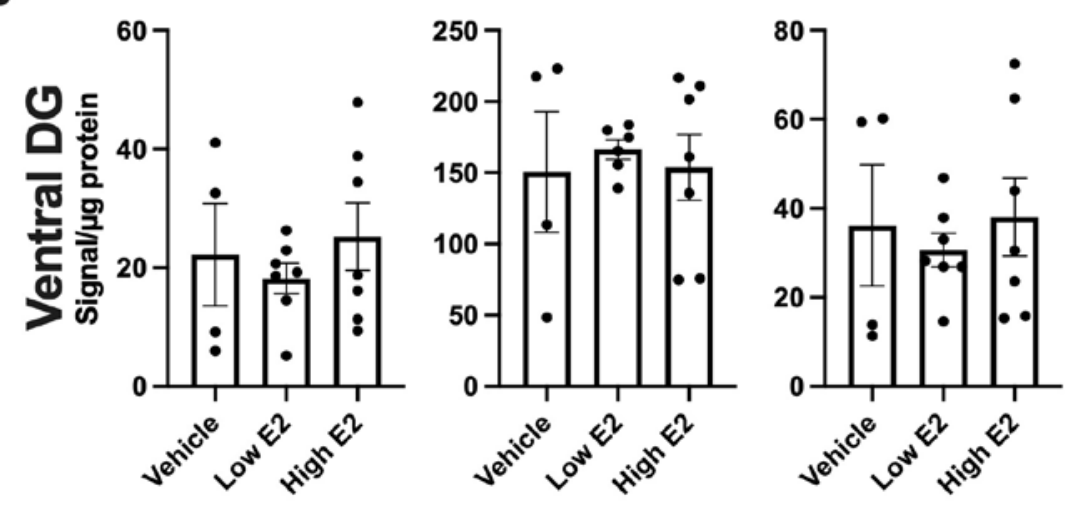

C
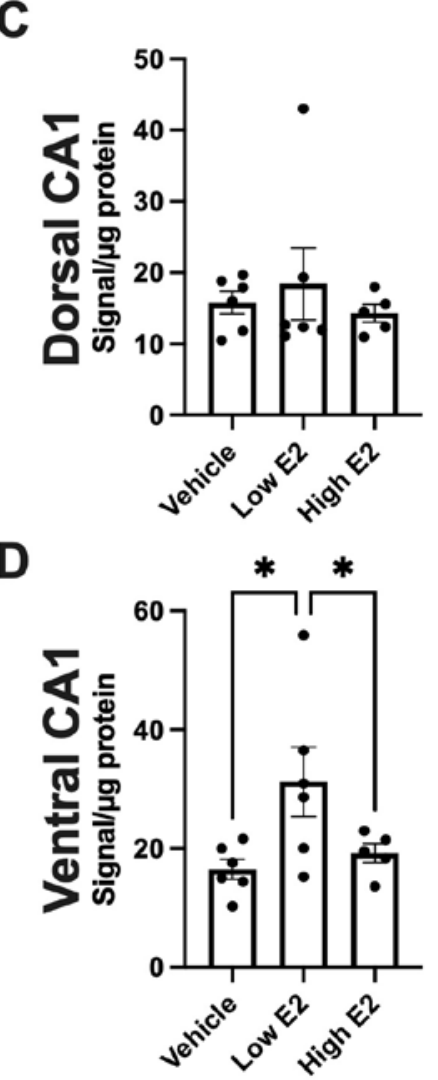
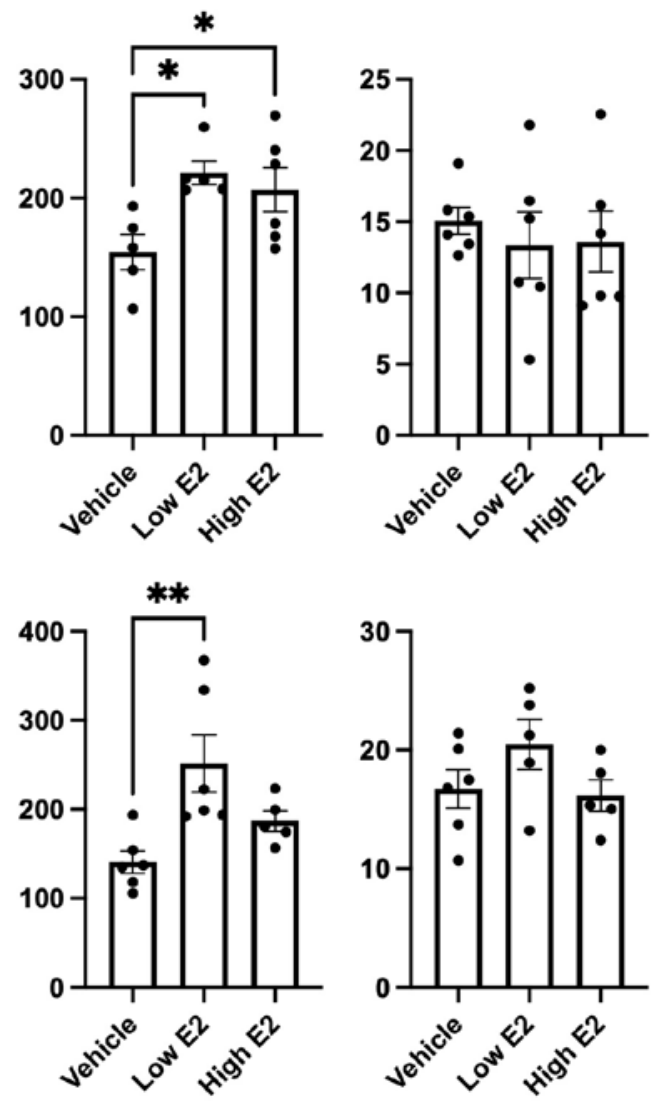